\title{
Difference in Quantity of Microbial Rumen Fluid of River Buffalo and Swamp Bufallo
}

\author{
Tintin Rostini \\ Universitas Islam Kalimantan \\ Kalimantan, Indonesia \\ tintin_rostini@yahoo.com
}

\author{
Irwan Zakir \\ Universitas Islam Kalimantan \\ Kalimantan, Indonesia \\ irwanzakir@gmail.com
}

\author{
Danang Biyatmoko \\ Universitas Lambung Mangkurat \\ Kalimantan, Indonesia \\ danangbiyatmoko@gmail.com
}

\begin{abstract}
The number of cellulolytic bacteria in buffalo rumen fluid has a difference with other ruminant rumen fluids. The purpose of this study was to determine the number and type of microbes from the rumen liquid of swamp buffalo, river buffalo and rumen fluid of Bali Cattle. The research material used rumen liquid from three types of livestock, namely swamp buffaloes, river buffaloes and cattle, average age of livestock +2 years, repeated 5 replications so that there were 15 samples of rumen fluid consisting of: $\mathrm{T} 1=$ liquid rumen of swamp buffalo, $\mathrm{T} 2$ = river buffalo rumen liquid and $\mathrm{T} 3=5$ rumen liquid of Bali cattle. The observed variables consisted of $\mathrm{pH}, \mathrm{NH} 3$, VFA, bacteria, protozoa and fungi. The results of the study showed that the number of microbes in swamp buffalo was more than river buffaloes and Bali cattle. It was concluded that the swamp buffalo rumen liquid had a greater number of microbes so that it had the potential as a probiotic for livestock.
\end{abstract}

Keywords-bacteria, cellulolytic, cow, rumen fluid, swamp buffalo

\section{INTRODUCTION}

In Indonesia, in general, there are two buffalo subspecies that are found, namely river buffalo (B. bubalis bubalis) from South Asia and swamp buffalo (B. bubalis carabanesis) originating from Southeast Asia. Swamp buffalo has characteristics of blackish gray skin, short and stocky body, round shape, broad chest circumference, short and straight legs, and wide and curved horns. As with river buffaloes which have skin characteristics that are deep black, dense and short, the neck and head are relatively smaller, the back is wide, and the horns are tightly circled like spirals [1].

The difference between them also lies in the way of life. River-type buffaloes enjoy flowing and clean water, while swamp-type buffaloes like to wallow in muddy marshes and stagnant water. In addition, the difference between swamp buffalo and river buffalo also lies in the difference in the number of chromosomes. Swamp buffalo has 48 chromosomes while river buffaloes have 50 chromosomes [2].

In general, swamp buffaloes and river buffaloes consume more forage, both those that grow in swamps and on land. Swamp forages that grow in swamps consist of grass and leguminosae, this forage has a good productivity and nutrient content, especially high protein content, these forages can be used as animal feed rich in nutrients [3]. Buffalo and cattle cattle generally have the same digestive system but physiologically there are differences in the rate of movement of feed, fluid volume and effectiveness of feed digestion [4].
This study aims to determine the number and types of microbes from the liquid rumen of swamp buffaloes, river buffaloes and Bali cattle in Kalimantan

\section{MATERIALS AND METHODS}

This research material uses buffalo rumen liquid from Martapura slaughterhouse in South Kalimantan. There were 15 samples of rumen liquid consisting of 5 swamp buffalo rumen samples, 5 samples from river buffalo rumen liquid and 5 samples of Bali rumen cow's liquid samples. Livestock used have traditional maintenance background with feed in the form of field grass, swamp grass, rice straw and corn straw.

Parameters analyzed were $\mathrm{pH}, \mathrm{NH} 3$, VFA, bacteria, and protoza. That is in the rumen fluid. Rumen fluid $\mathrm{pH}$ measurement using digital $\mathrm{pH}$ meter, NH3 measurement using the Conway method, while the VFA analysis of rumen fluid used the HPLC method, calculating bacteria and protozoa. The data obtained is calculated using the $\mathrm{T}$ Test [5].

\section{RESULTS AND DISCUSSION}

Fermentative Characteristics in Rumen Fluid

Types of livestock show different characteristics of cattle rumen liquid, at concentrations of rumen $\mathrm{pH}, \mathrm{NH} 3$ and total VFA of cattle rumen liquid are presented in Table 1.

TABLE 1. AVERAGE CHARACTERISTICS OF CATTLE RUMEN LIQUID

\begin{tabular}{lccc}
\hline \multicolumn{1}{c}{ Variable } & Swamp Buffalo & River buffalo & Bali Cattle \\
\hline PH & $5,62^{\mathrm{a}} \pm 0,3$ & $5.58^{\mathrm{a}} \pm 0.6$ & $6,46^{\mathrm{b}} \pm 0.2$ \\
NH3 (mM) & $9,46 \pm 2.6$ & $9,23 \pm 2.2$ & $10.78 \pm 1.2$ \\
VFA Total (mM) & $158,72 \pm 0.7$ & $155,62 \pm 1.8$ & $107,86 \pm 2.4$ \\
\hline
\end{tabular}

Diffrent superscripts along the colum indicate the significan differences $P<0.05$

The $\mathrm{pH}$ of the liquid rumen of buffaloes was significantly lower $(\mathrm{P}<0.05)$ than that of cattle. This is strongly influenced by the consumption of feed from livestock where buffalo feed both swamp buffaloes and river buffaloes consume higher feed dry matter than cows. This is related to the amount of VFA, the lower the rumen $\mathrm{pH}$, the number of VFA in the rumen will increase, namely for swamp buffalo (158.72 and river buffalo $(155.62 \mathrm{mM})$, but cattle only produce VFA concentrations of $107.86(\mathrm{mM}))$.The results of this study are in line with [1] that the good rumen $\mathrm{pH}$ is 5.88- 6.74 which has a good range for rumen microbial activity.

NH3 concentration of buffalo rumen fluid was not significantly different from $\mathrm{NH} 3$ concentration in cow rumen 
fluid ( $\mathrm{P}<0.05)$, this shows that the type of livestock did not show significant differences in NH3 concentration, so the activity of proteolytic bacteria as protein integration was not affected by feed so microbial growth was not disturbed. While [6] stated that rumen microbial survival at NH3 concentrations was $8-21 \mathrm{mM}$ for cattle and buffalo 7.1-17.7 $\mathrm{mM}$. In the study of $\mathrm{NH} 3$ concentrations both for buffaloes and for cattle is still within normal limits.

Rumen Microbial Population

Acetic acid and butyrate concentrations of swamp buffalo were higher than river buffaloes and Bali cattle (Table 2). Acetic acid and butyric acid are the main energy sources for ruminants, and are ketogenic, while propionic acid is used for gluconeogenesis or glucogenic. Table 2 shows the average difference in VFA from the liquid rumen of buffalo and cattle.

TABLE 2.AVERAGE DIFFERENCE IN VFA VARSIAL OF CATTLE RUMEN FLUID

\begin{tabular}{|c|c|c|c|}
\hline Variable & $\begin{array}{l}\text { Swamp } \\
\text { buffalo }\end{array}$ & $\begin{array}{c}\text { River } \\
\text { Buffalo } \\
\end{array}$ & Bali Cattle \\
\hline Acetic acid (ml/Mol) & $58,42^{\mathrm{c}} \pm 2.8$ & $52,62^{\mathrm{b}} \pm 3.2$ & $47,26^{\mathrm{a}} \pm 2.6$ \\
\hline Propionate acid (ml/Mol) & $25,26^{\mathrm{b}} \pm 4.1$ & $23,25^{\mathrm{a}} \pm 2.3$ & $22,87^{\mathrm{a}} \pm 1.5$ \\
\hline Butyric acid (ml/Mol) & $11.46^{\mathrm{a}} \pm 1.2$ & $11,97^{\mathrm{a}} \pm 2.2$ & $17,81^{\mathrm{b}} \pm 1.2$ \\
\hline Iso Valerat(ml/Mol) & $2,26 \pm 1.4$ & $2,18 \pm 1.2$ & $1,94 \pm 1.1$ \\
\hline Valerat $(\mathrm{ml} / \mathrm{Mol})$ & $1,92 \pm 1.3$ & $1,87 \pm 0.8$ & $1,38 \pm 1.1$ \\
\hline Ratio of acetate propionate & $2,31 \pm 0.8$ & $2,26 \pm 0.3$ & $2,07 \pm 0.6$ \\
\hline
\end{tabular}

The ratio of acetate and propinate to rumen of buffalo and bali cattle showed no significant difference $(\mathrm{P}<0.05)$, this indicates that the ability to increase productivity in bali cattle and swamp buffaloes and river buffaloes has the same ability to produce productivity or increase body weight. high.

The population of bacteria that develops a lot in rumen fluid is proteolytic bacteria both in the rumen of swamp buffalo fluid and cow rumen fluid. The results showed significant differences $(\mathrm{P}<0.05)$ of proteolytic bacteria in different types of livestock. The population of bacteria in swamp buffalo is higher than river buffalo and bali cattle. This shows that swamp buffaloes are accustomed to and only given forage, so that bacteria that are more developed are species of Proteolytic bacteria. This is in line with [7] that livestock that are only given forage will develop proteolytic bacteria. Proteins will be integrated by protease enzymes produced by proteolytic bacteria into peptides and amino acids.

TABLE 3. AVERAGE POPULATION OF MICROBIAL AMOUNT OF CATTLE RUMEN FLUID (M/MOL

\begin{tabular}{|c|c|c|c|}
\hline Variable & Swamp Buffalo & $\begin{array}{c}\text { River } \\
\text { Buffalo }\end{array}$ & Bali Cattle \\
\hline Total Bacteria & $12,82^{\mathrm{c}} \pm 1,3$ & $10,08^{\mathrm{b}} \pm 2.6$ & $9,76^{\mathrm{a}} \pm 1.2$ \\
\hline Proteolytic bacteria & $11,24^{\mathrm{c}} \pm 0.8$ & $9,88^{\mathrm{b}} \pm 1,2$ & $8,92 \mathrm{a} \pm 2,3$ \\
\hline Cellolytic bacteria & $10,06^{\mathrm{b}} \pm 1.6$ & $9,53^{\mathrm{b}} \pm 1.8$ & $8,76^{a} \pm 0.7$ \\
\hline Amylolytic bacteria & $9,87^{\mathrm{b}} \pm 0.8$ & $9,66^{\mathrm{b}} \pm 1.6$ & $8,41^{\mathrm{a}} \pm 1.8$ \\
\hline Protozoa & $4,93^{\mathrm{b}} \pm 1.7$ & $4,17^{\mathrm{b}} \pm 2.6$ & $5,79^{\mathrm{a}} \pm 2.5$ \\
\hline
\end{tabular}

Diffrent superscripts along the colum indicate the significan differences $P<0.05$
Table 3 shows that swamp buffalo rumen fluid has a higher bacterial content and less protozoa compared to Bali cattle $(\mathrm{P}<0.05)$ while $\mathrm{pH}$ does not show significant differences. Protozoa population in buffalo rumen is less than the protoza population in cattle, this shows that there is a chance that rumen bacteria to breed more. This is in line with the research of [8] resulting in lower numbers of protozoa in buffalo (4.68 $\log 10)$ compared to the amount of cow rumen fluid protozoa $(5.19 \log 10)$, while [8] that the presence of protozoa in the rumen can reduce the number of bacteria. The results showed that the number of protoza rumen of swamp buffalo was lower than that of river buffaloes or in cattle so that the number of bacteria was more to produce more VFA bacteria. The results of this study are in line with the results of [6], resulting in fewer protozoan populations in buffalo rumen fluid than cattle, the least amount of protozoa causing the development of a higher bacterial population.

\section{CONCLUSION}

The amount of microbial fluid in buffalo rumen is more than that of cattle

\section{ACKNOWLEDGMENT}

Thanks are conveyed to the director of research and community service, direktorate general of Higher Educatioan (DRPM Dikti) who has funded this research in the competency grant research scheme for the 2018 budget year.

\section{REFERENCES}

[1] Pirmohammadi R, Yansari AT. Hamidi Ba, Manafiazar GH, "Efeect of dufferent fibrous and non fiber carbohydratae levels on nutrient digestibility of total muxed ration using in vivo in Buffalo," Ital. Journal Anim Scirncr 6:476-479, 2007.

[2] Rostini $\mathrm{T}$ dan Zakir I, "Pengaruh Penggunaan Hijauan Rawa Terhadap Performans Produksi, Jumlah Nematoda Dan Profil Metabolik Darah Kambing," Jurnal Veriner. Vol 18(3):469-477, 2017.

[3] Rostini, T. Produktivitas dan Pemanfaatan tumbuhan rawa di Kalimantan selatan sebagai hijauan pakan berkelanjutan. Disertasi Doktor. Institut Pertanian Bogor, 2014.

[4] Haryanto B dan Thalib A. Emisi metana dari fermentasi enteric : kontribusinya secara nasional dan factor-factor yang mempengaruhinya pada ternak. Wartazoa 19:157-165,2009.

[5] Steel RGD , Torrie JH. Prinsip dan prosedur statistik; pendekatan biometrik. Sumantri B. Penerjemahan, Jakarta. Gramedia Terjemahan dari : Principle and procedure of Statistics ,1995.

[6] Wanapat M, dan Rowlinson P. Nutrition and feeding of swamp buffalo feed reasources and rumen approach. Tal J. Anim Sci . 6: 6778,2007 .

[7] Kamra DN Rumen Microbial ecosytem. Jurnal Current Science. 89(1); 124-135,2005.

[8] Hanim, C.1.M. Yusiati and s. Alim. Efect of saponin as defaunating agent on in vitro eruminal fermentation of forage and concerate . Jurnal Pengembangan Peternakan Tropis. 34:231-235 ,2009. 